\title{
Photodegradation Properties of Earlywood and Latewood Spruce Timber Surfaces
}

\author{
Edina PREKLET ${ }^{\mathrm{a}}-$ László TOLVAJ $^{\mathrm{a}^{*}}-$ Satoru TSUCHIKAWA $^{\mathrm{b}}-$ Dénes VARGA $^{\mathrm{a}}$ \\ ${ }^{a}$ Institute of Physics and Electrotechnics, University of Sopron, Sopron, Hungary \\ ${ }^{\mathrm{b}}$ Graduate School of Bioagricultural Sciences, Nagoya University, Nagoya, Japan
}

\begin{abstract}
Spruce (Picea abies Karst.) samples were irradiated using an ultraviolet light emitter mercury vapour lamp. The examined specimen surfaces contained earlywood or latewood to determine the photodegradation properties of these two tissue types. The generated chemical changes were monitored by diffuse reflectance Fourier transformed infrared spectroscopy. The difference spectrum method was used to present absorption changes. The earlywood suffered considerably greater degradation than the latewood during the UV irradiation. Most of the lignin molecules in the examined surface layer degraded during the first 11 days of UV irradiation for both earlywood and latewood. Results demonstrated that two types of unconjugated carbonyls absorbing at 1705 and $1764 \mathrm{~cm}^{-1}$ wavenumbers were created during the photodegradation. Time dependence of the absorption changes showed correlation between the guaiacyl lignin degradation and the generation of unconjugated carbonyl group absorbing at $1764 \mathrm{~cm}^{-1}$ wavenumber.
\end{abstract}

lignin / ultraviolet irradiation / infrared spectroscopy

Kivonat - A lucfenyő faanyag korai és késői pásztájának fotodegradációs tulajdonságai. Luc (Picea abies Karst.) famintákat világítottunk meg higanygőz lámpa által kibocsátott ultraibolya fénnyel. A vizsgált minták felszíne korai- vagy késői pásztát tartalmazott, hogy meghatározhassuk a kétféle pászta fotodegradációs tulajdonságait. A diffúz visszaverődésen alapuló Fourier transzformációs infravörös spektroszkópia segítségével követtük nyomon a kémiai változásokat. Az abszorpcióban bekövetkezö módosulásokat a kalkulált különbségi színképek tükrözik. A korai pászta számottevően nagyobb degradációt szenvedett az UV besugárzás hatására, mint a késői pászta. A vizsgált felületi rétegben lévő lignin molekulák többsége degradálódott az UV besugárzás első 11 napja során. Az eredmények azt mutatják, hogy kétfajta nemkonjugált karbonil csoport keletkezett a fotodegradáció során, melyek abszorpciója az 1705 és az $1764 \mathrm{~cm}^{-1}$ hullámszámoknál jelentkezett. A kezelési idő függvényében vizsgált gvajacil lignin degradációja és az $1764 \mathrm{~cm}^{-1}$ hullámszámnál abszorbeáló nemkonjugált karbonil csoportok keletkezése között ok-okozati összefüggést találtunk.

lignin / ultraibolya besugárzás / infravörös színképelemzés

\footnotetext{
*Corresponding author: tolvaj.laszlo@uni-sopron.hu; H-9400 SOPRON, Bajcsy-Zs. u. 4, Hungary
} 


\section{INTRODUCTION}

Colour harmony is one of nature's most beautiful creations. Machined wood surfaces in any anatomical plane present the colour diversity of the interior lumen surfaces, cell wall, earlywood, and latewood zones. The colour hue of wood between red and yellow generates a feeling of warmth.

This colour harmony of solid wood is sensitive to light, heat and humidity. Wood surfaces may degrade due to the combination of these factors and subsequently erode and become grey. Outdoor weathering tests of wood are highly complex. Outdoor weathering tests have some unavoidable disadvantages for scientific research because weather conditions are neither controllable nor repeatable. Therefore, the weathering properties of wood are usually investigated under artificial conditions.

The main factor causing the greatest changes in wood colour is exposure to sunlight (Tolvaj - Mitsui 2005, Zivkovic et al.2014). The ultraviolet (UV) part of sun radiation causes the main degradation of wooden surfaces (Agresti et al. 2013, Yildiz et al. 2013, Borda Popescu 2019, Liu X et al. 2016, 2019, Liu R et al. 2019). Chemical analyses showed that the deterioration is mainly related to lignin decomposition (Pandey 2005, Teaca et al. 2013, Timar et al. 2016, Arpaci et al. 2020). The chromophoric groups of lignin are strong UV light absorbers. The energy of the absorbed UV photons is enough to create free phenoxyl radicals. These free radicals react with oxygen to produce carbonyl groups (Tolvaj - Faix 1995, Bonifazi et al. 2017, Varga et al. 2017, Jankowska et al. 2020). Rain is able to leach out some parts of the degradation products. The chemical background of leaching was recently investigated (Kannar et al. 2018, Bejó et al. 2019, Varga et al. 2020, Pásztory et al. 2020). The infrared (IR) spectrum analysis showed that the leached surface suffered greater lignin degradation than the dry surface. The photodegradation-generated compounds, containing unconjugated carbonyl groups, were leachable. According to the Arrhenius law, increasing temperatures intensify the effect of photodegradation (Tolvaj et al. 2013, 2015, Varga et al. 2017, Preklet et al. 2018).

Differences in the weathering properties of earlywood and latewood are well visible after long-term outdoor exposure. Earlywood surfaces became more eroded than latewood surfaces. Though this phenomenon is mentioned in some papers (Turkulin - Sell 2002, Tolvaj et al. 2014, Sandak et al., Šterrbová et al. 2020), the chemical background has not been investigated yet.

The aim of this study was to monitor chemical changes of photodegraded earlywood and latewood surfaces. IR spectroscopy was the applied analytical tool.

\section{MATERIALS AND METHODS}

Spruce (Picea abies Karst.) specimens with low extractive content were chosen for the degradation test. The specimen dimensions were $30 \mathrm{~mm}$ x $10 \mathrm{~mm}$ x $5 \mathrm{~mm}$ (long. $\mathrm{x}$ tang. $\mathrm{x}$ rad.). Both investigated series were represented by three samples. IR measurement was completed on two fixed locations of the tangential surface of each sample (both earlywood and latewood samples). The tangential surface of the specimens contained only earlywood or latewood. A double mercury vapour lamp, with a total electric power of $800 \mathrm{~W}$, as a strong UV light emitter, generated the light irradiation. The UV radiation was $80 \%$ of the total emission of the lamps. Specimens were located at a distance of $64 \mathrm{~cm}$ from the lamp. The temperature in the chamber was $50^{\circ} \mathrm{C}$ during the irradiation. The duration of the first UV irradiation period was 24 hours. After this period, UV radiation time was doubled (48 hours), and the 48 -hour period of UV radiation was repeated up to 20 days (the last period was 36 hours). The shorter UV 
radiation time was chosen at the beginning of the treatment because the degradation effect of UV radiation is very intensive at the beginning of the treatment.

Diffuse reflectance infrared Fourier transform (DRIFT) spectrum of the samples was measured before and after each treatment period. Measurements were carried out with an IR spectrophotometer (JASCO FT/IR 6300). The resolution was $4 \mathrm{~cm}^{-1}$ and 64 scans were measured and averaged. The background spectrum was obtained against an aluminium plate. Two-point baseline correction at $3800 \mathrm{~cm}^{-1}$ and at $1900 \mathrm{~cm}^{-1}$ was executed. The spectral intensities were calculated in Kubelka-Munk (K-M) units. The spectra were normalised to the band maximum around $1375 \mathrm{~cm}^{-1}$. The intensity of spectra was adjusted to 1.0 by this normalisation at a maximum of around $1375 \mathrm{~cm}^{-1}$. This $\mathrm{C}-\mathrm{H}$ band of cellulose is often used as an internal standard because of its high intensity, central position, and strong stability during photodegradation. The difference spectrum was calculated by subtracting the initial IR data from the data of the treated sample. In this case, absorption increase is represented by positive band while negative band represents absorption decrease. Details are described in a previous work (Csanady et al. 2015). The band assignment is presented in Table 1.

Table 1. Characteristic IR bands of wood (place of maximum) and band assignments (Csanády et al. 2015)

\begin{tabular}{cl}
$\begin{array}{c}\text { Wavenumber } \\
\left(\mathbf{c m}^{-1}\right)\end{array}$ & \\
\hline $3600-3550$ & Intramolecular hydrogen bond in a phenolic group (in lignin) and weakly \\
& bounded absorbed water \\
$3360-3310$ & O(3)H. .O(5) intramolecular hydrogen bonds in cellulose \\
2928 & CH2 stretching asymmetric \\
2854 & Symmetric CH ${ }_{2}$ stretching \\
$1770-1757$ & C=O stretching vibration of non-conjugated ketones and $\gamma$ lactones \\
$1736-1705$ & C=O stretching vibration of carboxyl groups and acetyl groups in \\
& hemicelluloses (xyloglucan) \\
$1660-1653$ & conjugated C-O in quinines coupled with C=O stretching of various groups \\
& (flavones) \\
$1628-1618$ & C=O stretching in flavones \\
$1604-1594$ & aromatic skeletal breathing with CO stretching (syringil lignin) \\
$1512-1505$ & aromatic skeletal (guaiacyl lignin) \\
$1478-1476$ & C-H deformation in lignin \\
$1465-1457$ & C-H deformation in xylan \\
1435 & C-H deformation in lignin and carbohydrates \\
$1390-1380$ & C-H deformation in cellulose and hemicellulose \\
$1369-1366$ & Aliphatic C-H stretching in methyl and phenol OH \\
$1333-1342$ & C-H deformation, C-OH stretching, syringyl ring \\
1319 & C-H - Hagging, C-H deformation (conifers) \\
1285 & C-H bending mode in cellulose \\
$1285-1275$ & Caryl-O, guaiacyl ring breathing with CO stretching \\
$1240-1230$ & C-O linkage in guaiacyl aromatic methoxyl groups and acetyl groups in \\
& xyloglucan \\
$1183-1175$ & C-O-C stretching (asymm.) in cellulose and hemicelluloses \\
$1158-1156$ & C-O-C stretching in pyranose rings, C=O stretching in aliphatic groups \\
$1138-1131$ & C-O-C stretching (symm.), arom. C-H i.p. deformation, glucose ring vibration \\
$1108-1106$ & C-O-C stretching \\
$1078-1076$ & C-O stretching mainly from C(3)-O(3)H in cellulose I \\
$1050-1045$ & C-O and C-C stretching in cellulose and hemicelluloses \\
898 & C-H deformation of cellulose \\
\hline &
\end{tabular}




\section{RESULTS AND DISCUSSION}

Infrared spectroscopy is a good measurement technique to determine the chemical changes of wood caused by light irradiation. Figure 1 illustrates the IR absorption spectrum of spruce earlywood before and after three days of UV irradiation. Absorption intensities are presented in Kubelka-Munk (KM) units. The left half of the spruce absorption spectrum consists of two broad bands. The higher peak around $3450 \mathrm{~cm}^{-1}$ belongs to the absorption of hydroxyl groups. Hydroxyl groups are located at various places in cellulose, hemicellulose, and lignin. The $\mathrm{OH}$ groups are located in many different positions surrounded by diverse chemical compounds. Surrounding chemical groups perturb the vibration of hydroxyl groups, which slightly modifies the wavenumber of the absorption band. That is why the hydroxyl groups have absorption at different wavenumbers causing a rather wide absorption band. Water in the wood also results in absorption in this region. The next band around $2900 \mathrm{~cm}^{-1}$ represents the absorption of different methyl groups. This is also a multiple absorption band.

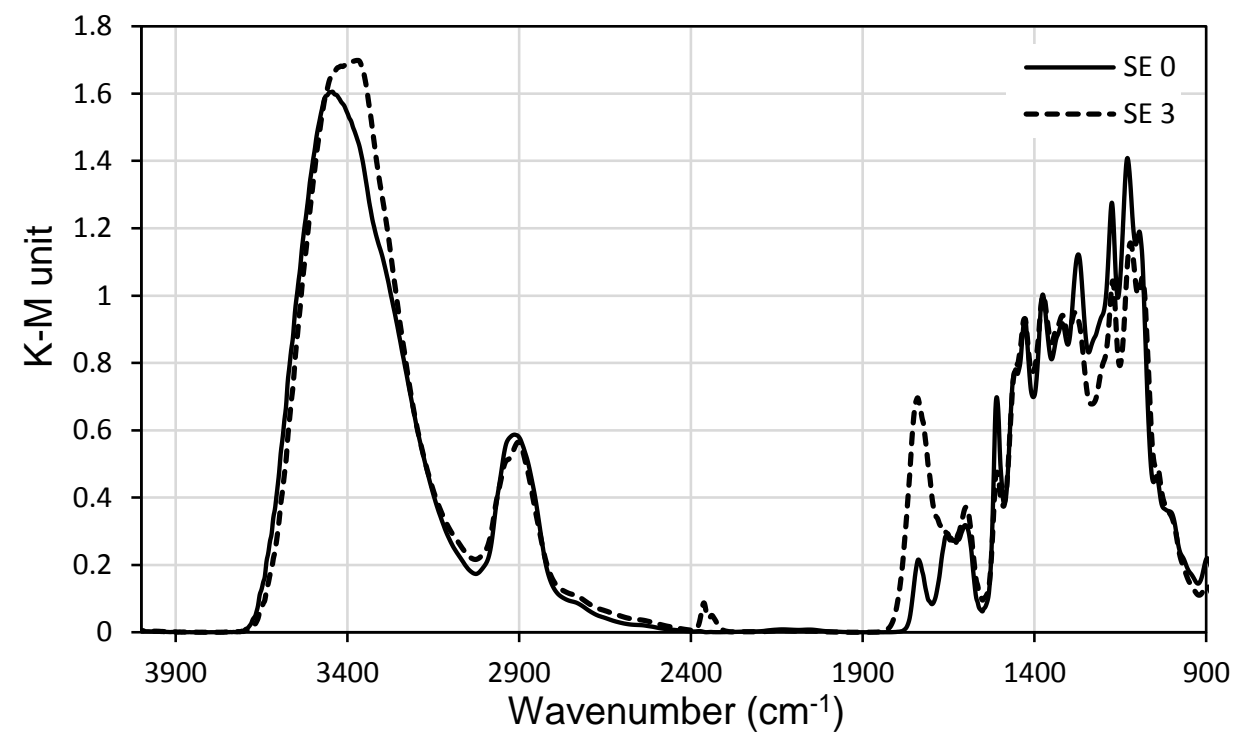

Figure 1. Absorption spectra of spruce (S) earlywood (E) before treatment (O) and after three days of UV irradiation

The right side of the spectrum (fingerprint region between $900-1900 \mathrm{~cm}^{-1}$ ) consists of several overlapping bands generated by the absorption of cellulose, hemicelluloses, and lignin. As the bands highly overlap each other, most of the peak maxima are not real due to the superposition of two or more individual bands. (This phenomenon is clearly visible when comparing the form of the bands around $1740 \mathrm{~cm}^{-1}$ in Figures 2-4.)

The unconjugated carbonyl band is located between 1650 and $1820 \mathrm{~cm}^{-1}$. This carbonyl band is the superposition of some individual bands. A previous study determined four bands in the unconjugated carbonyl region (Varga et al. 2017). Hence most publications treat the band of unconjugated carbonyls as a single absorption band with a maximum around $1740 \mathrm{~cm}^{-1}$. The region between $950-1550 \mathrm{~cm}^{-1}$ wavenumbers has many overlapping bands. The most important peaks are the following: the peaks of the aromatic ring vibrations arising from lignin are at $1510 \mathrm{~cm}^{-1}$; the peaks of the aromatic C-H deformation are at 1469 and $1428 \mathrm{~cm}^{-1}$; the absorption of the guaiacyl ring breathing is located at $1270 \mathrm{~cm}^{-1}$.

The absorption wavenumbers of the asymmetric and symmetric stretching of ether bond in cellulose are located around 1170 and $1130 \mathrm{~cm}^{-1}$. The aromatic $\mathrm{C}-\mathrm{H}$ deformation and the glucose ring vibration also generate absorption around $1130 \mathrm{~cm}^{-1}$. 
Chemical changes created by UV irradiation can be seen in Figure 1. The number of hydroxyl groups absorbing around $3400 \mathrm{~cm}^{-1}$ increased and the groups absorbing around $3600 \mathrm{~cm}^{-1}$ decreased during the three-day UV irradiation period. A great absorption increase appeared around $1740 \mathrm{~cm}^{-1}$. The place of maximum shifted towards smaller wavenumbers and the band became wider. The absorption decrease of aromatic skeletal vibration of lignin at $1510 \mathrm{~cm}^{-1}$ is hardly visible together with the absorption decrease of ether bonds between $1120-1180 \mathrm{~cm}^{-1}$. The difference spectrum method solves these problems. Creating the difference spectrum (irradiated minus initial) provides a more transparent figure since only those absorption bands appear where actual changes occurred. (The absorption increase is represented by positive band while negative band represents the absorption decrease.) The real changes are clearly visible in Figure 2, where the difference spectra are presented for both earlywood and latewood generated by one-day and three-day UV irradiation. The negative peak at $1510 \mathrm{~cm}^{-1}$ belongs to the aromatic skeletal vibration of guaiacyl lignin. This negative peak is detectable together with the absorption decrease of the aromatic C-H deformation at 1470 and $1430 \mathrm{~cm}^{-1}$ and with the absorption decrease of the guaiacyl ring breathing at $1270 \mathrm{~cm}^{-1}$. The greatest absorption decrease is visible at 1174 and $1133 \mathrm{~cm}^{-1}$. The first decrease belongs to the asymmetric stretching of ether bond in cellulose. The second decrease belongs to the symmetric stretching of ether bond, the aromatic $\mathrm{C}-\mathrm{H}$ deformation, and to the glucose ring vibration. These absorption decreases indicate the ether splitting and the depolymerisation of cellulose.

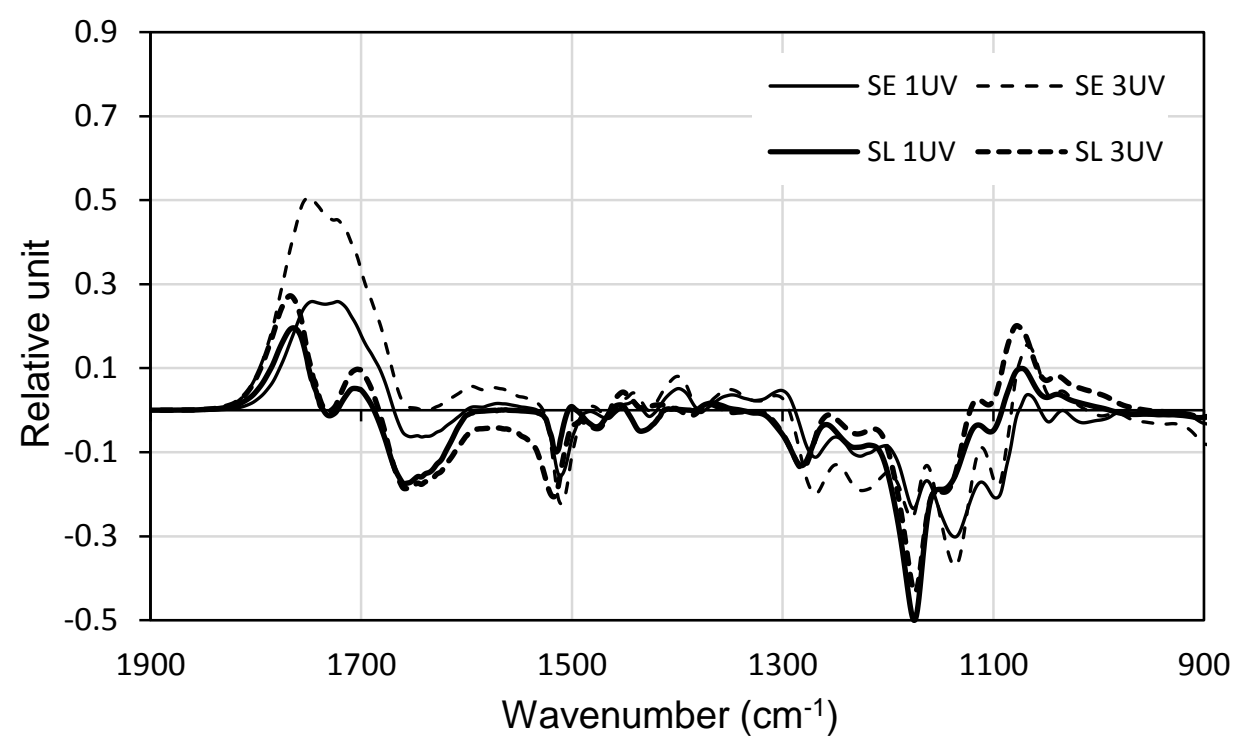

Figure 2. Absorption difference spectrum of spruce $(S)$ earlywood $(E)$ and latewood $(L)$ generated by UV irradiation (in days).

Free radicals were generated during lignin degradation. These free radicals react with oxygen to produce carbonyl groups. The absorption increase of unconjugated carbonyls is visible in Figures $2-4$ in the $1680-1820 \mathrm{~cm}^{-1}$ wavenumber interval. Two bands rose in this region for both earlywood and latewood at 1705 and $1764 \mathrm{~cm}^{-1}$ wavenumbers. The band at $1764 \mathrm{~cm}^{-1}$ represents the absorption of CO stretching for unconjugated ketones and $\gamma$ lactones generated by the oxidation after the splitting of the aromatic ring. The band at $1705 \mathrm{~cm}^{-1}$ represents the absorption of aliphatic carboxyl groups. Although the locations of these peaks should be the same, the intensities and the apparent places of the peaks are different for earlywood and latewood. Latewood produced a smaller absorption increase than earlywood. Great intensity difference was found between the two peaks. The peak intensity at $1705 \mathrm{~cm}^{-1}$ 
was small compared to the neighbouring peak. The two bands are well separated because of the low intensities. In contrast, the peak intensity at $1705 \mathrm{~cm}^{-1}$ for earlywood is almost equal to that of the neighbouring peak at $1764 \mathrm{~cm}^{-1}$. The superposition of the two bands is visible in Figure 2. The real positions of the peaks are not visible since the superposition pulled the locations of the peaks toward each other. These two bands finally joined into one single band after 20-day UV irradiation (Figure 4). The negative intensity change of the peak at $1510 \mathrm{~cm}^{-1}$ increased during UV irradiation. (Time dependence of this intensity will be discussed later.)

The intensity of the two types of ether bond at 1174 and $1133 \mathrm{~cm}^{-1}$ decreased, but in different ways for earlywood and latewood. The two negative peak intensities were almost equal for earlywood. The peak at $1133 \mathrm{~cm}^{-1}$ was a little greater than the peak at $1174 \mathrm{~cm}^{-1}$. Latewood showed opposite peak intensities. The peak at $1174 \mathrm{~cm}^{-1}$ presented the greatest negative change and the peak at $1133 \mathrm{~cm}^{-1}$ is visible as a shoulder. There is a visible positive peak at $1068 \mathrm{~cm}^{-1}$. This positive peak is associated with the $\mathrm{C}-\mathrm{O}$ bonds stretching in cellulose and hemicelluloses.

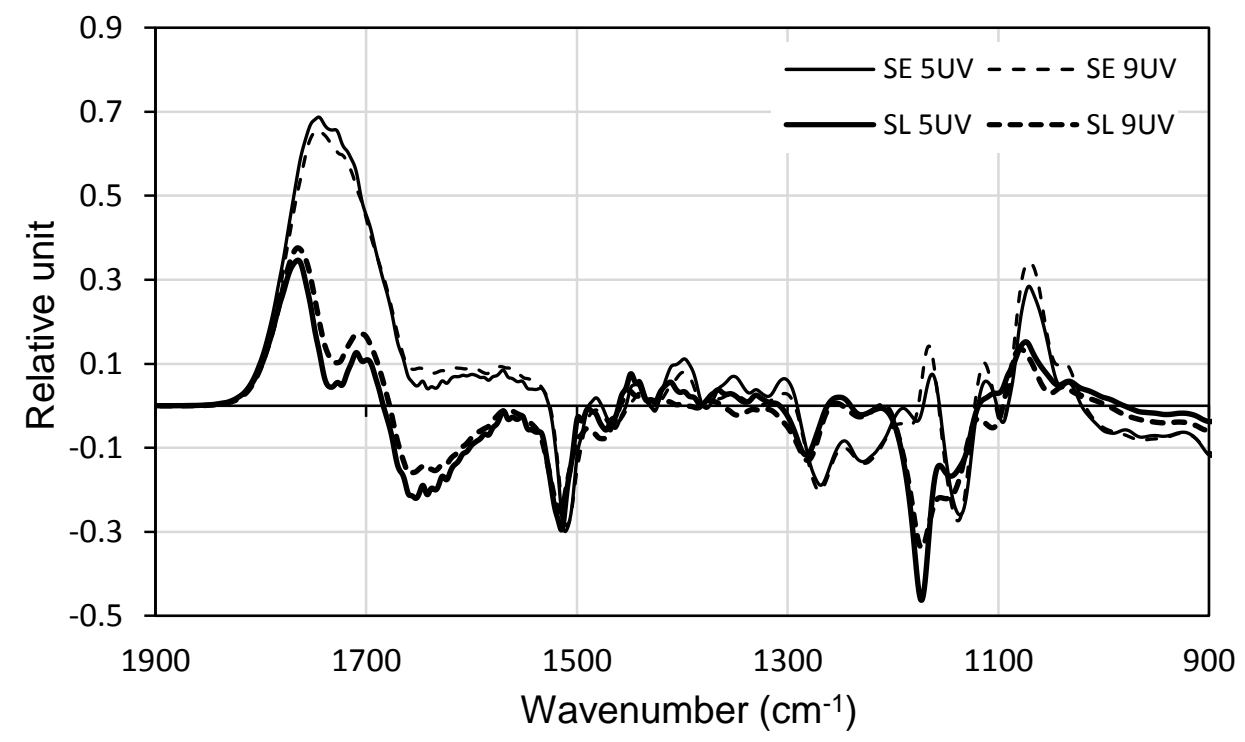

Figure 3. Absorption difference spectrum of spruce $(S)$ earlywood $(E)$ and latewood $(L)$ generated by UV irradiation (in days)

The prolonged treatment time intensified the absorption changes (Figures 3 and 4). The absorption intensities of the two types of unconjugated carbonyl groups at 1705 and $1764 \mathrm{~cm}^{-1}$ wavenumbers increased with longer irradiation. (The time dependence of these intensities will be discussed later.) The two bands composed a single band after nine days of irradiation for earlywood, which remained up to the end of treatment. The peak intensity at $1705 \mathrm{~cm}^{-1}$ was growing faster than the peak intensity at $1764 \mathrm{~cm}^{-1}$ for latewood, and it became only a shoulder after 20 days of irradiation.

The evaluation of the changes in the ether bond region is difficult because the KubelkaMunk equation does not provide the absorption spectrum properly if the absorption is high and the surface roughness changes. A previous study showed that photodegradation increases the surface roughness of wood (Tolvaj et al. 2014). The roughness increase lifts up the intensities due to the increasing scattering. A detailed discussion of this phenomenon can be found in a previous study (Tolvaj et al. 2011). The lifting effect overlaps the real absorption changes, interfering with the evaluation of IR spectrum in the $1000-1200 \mathrm{~cm}^{-1}$ wavenumber interval. 


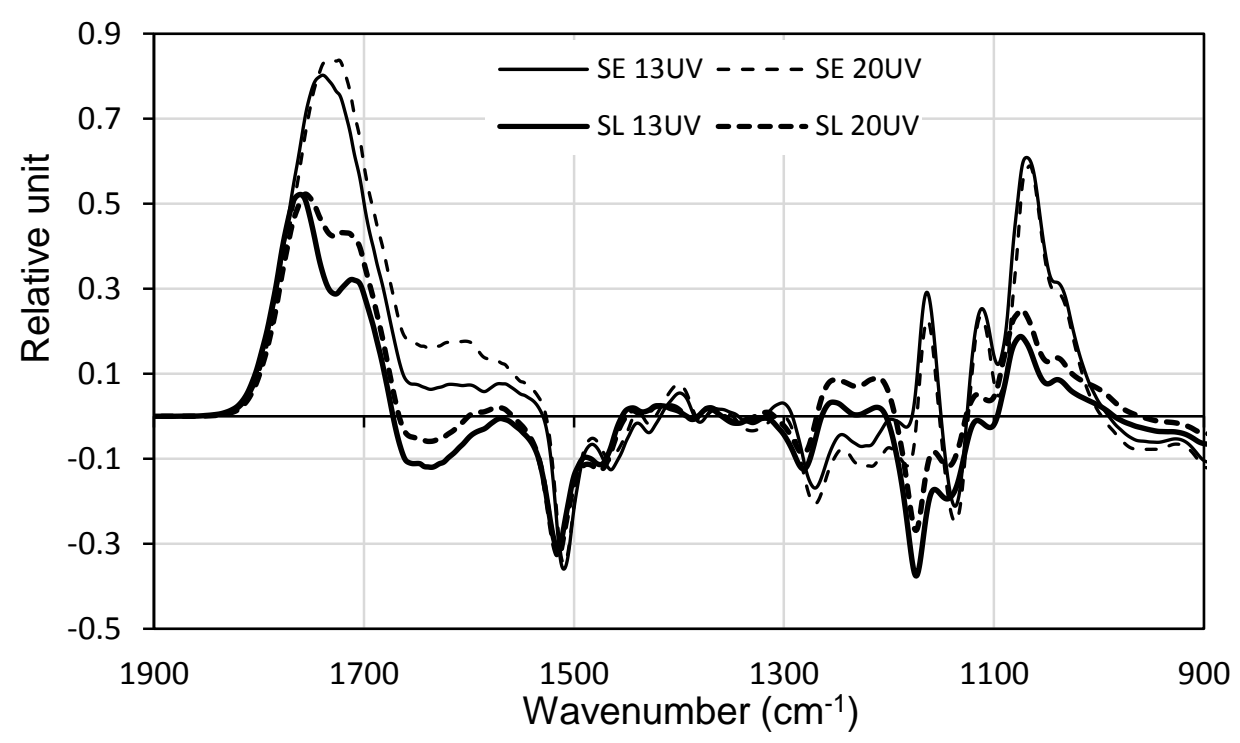

Figure 4. Absorption difference spectrum of spruce $(S)$ earlywood $(E)$ and latewood $(L)$ generated by $U V$ irradiation (in days).

Figures 2-4 present the absorption decrease of guaiacyl lignin. However, due to overlapping, these figures do not clearly show the intensity changes of this negative peak. Figure 5 clearly demonstrates the absorption change at $1510 \mathrm{~cm}^{-1}$ in all investigated situations. The results show that earlywood suffered greater lignin degradation than latewood. The higher extractive content in latewood provided greater protection for lignin than the lower extractive content in earlywood. The protecting effect of the extractives was demonstrated by previous studies (Németh et al. 1992, Varga et al. 2020). Lignin degradation was fast at the beginning of the treatment and stopped after 11 days of UV irradiation for both earlywood and latewood. The reason could be that most of the lignin molecules of the examined surface layer degraded during the first 11 days of UV irradiation.

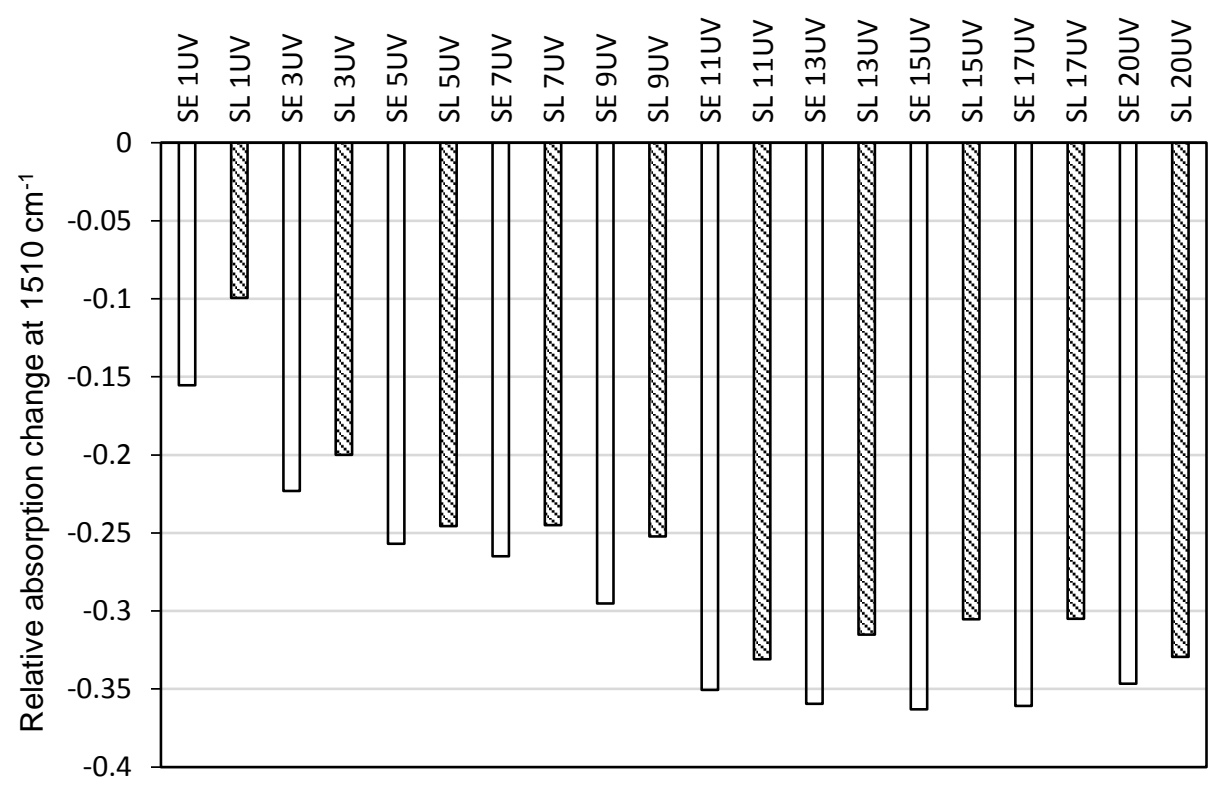

Figure 5. Absorption band intensity change of guaiacyl lignin in spruce (S) earlywood (E) and latewood $(L)$ at $1510 \mathrm{~cm}^{-1}$ wavenumber generated by UV irradiation (in days) 
Figure 6 presents the intensity changes of the unconjugated carbonyl groups absorbing at the $1764 \mathrm{~cm}^{-1}$ wavenumber. Absorption intensity increased continuously for both earlywood and latewood up to the thirteenth day of UV irradiation, and decreased slightly after that. The decrease after the thirteenth day of treatment might not be a real decrease. The values were read exactly at $1764 \mathrm{~cm}^{-1}$ wavenumber; however, changes in the overlapping band at the $1705 \mathrm{~cm}^{-1}$ wavenumber probably modified the real values. UV irradiation generated greater absorption increase for earlywood than for latewood. The trend seems to be opposite for oneday treatment, while Figure 2 clearly shows that earlywood produced greater absorption increase than latewood during the first day of irradiation. The tendency of the absorption changes at $1764 \mathrm{~cm}^{-1}$ was a mirror image of lignin degradation at $1510 \mathrm{~cm}^{-1}$. This fact demonstrates the correlation between lignin degradation and the generation of unconjugated carbonyl groups absorbing at $1764 \mathrm{~cm}^{-1}$. Many studies deal with the correlation between lignin degradation and the generation of new unconjugated carbonyl groups (Pandey 2005, Agresti et al. 2013, Timar et al. 2016, Bonifazi et al. 2017, Reinprecht et al. 2018). However, all of these publications use the complete integrated unconjugated carbonyl band as the participant in the correlation. Our results demonstrate that only one component of unconjugated carbonyl band (at $1764 \mathrm{~cm}^{-1}$ wavenumber) participates in this correlation.

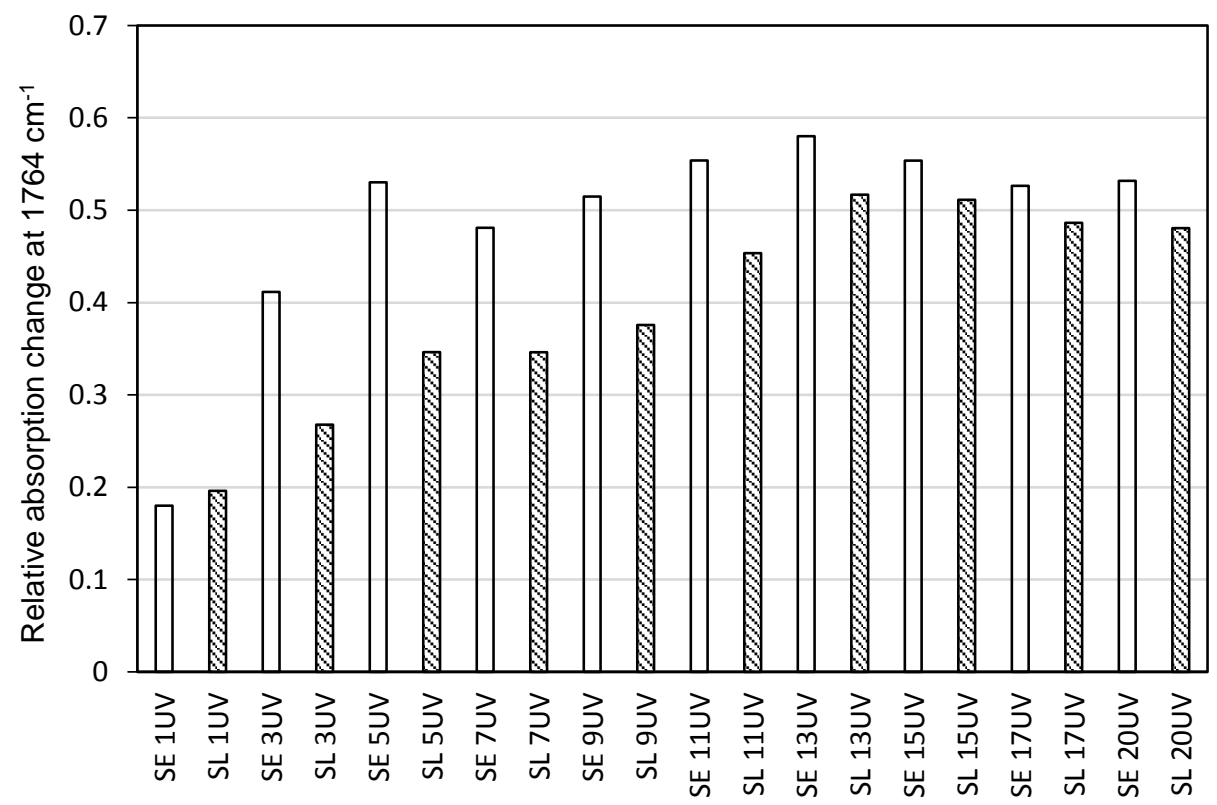

Figure 6. Absorption band intensity change of the unconjugated carbonyls at $1764 \mathrm{~cm}^{-1}$ for spruce $(S)$ earlywood $(E)$ and latewood $(L)$ generated by UV irradiation (in days)

Figure 7 shows the irradiation time dependence of the unconjugated carbonyls absorbing at the $1705 \mathrm{~cm}^{-1}$ wavenumber. Earlywood presented rapid absorption increase at the beginning of the UV irradiation, followed by a moderate increase up to the end of the treatment. Latewood produced only a small absorption increase during the first day of irradiation. This small value was followed by continuous absorption increase throughout the whole investigated treatment period. In the second part of the treatment, latewood produced more intensive absorption increase than the earlywood. The absorption increase at $1705 \mathrm{~cm}^{-1}$ does not show similar time dependence to the lignin degradation. This finding raises the question of whether the unconjugated carbonyls absorbing at $1705 \mathrm{~cm}^{-1}$ are derived from the degradation of lignin. This phenomenon requires further chemical investigations. 


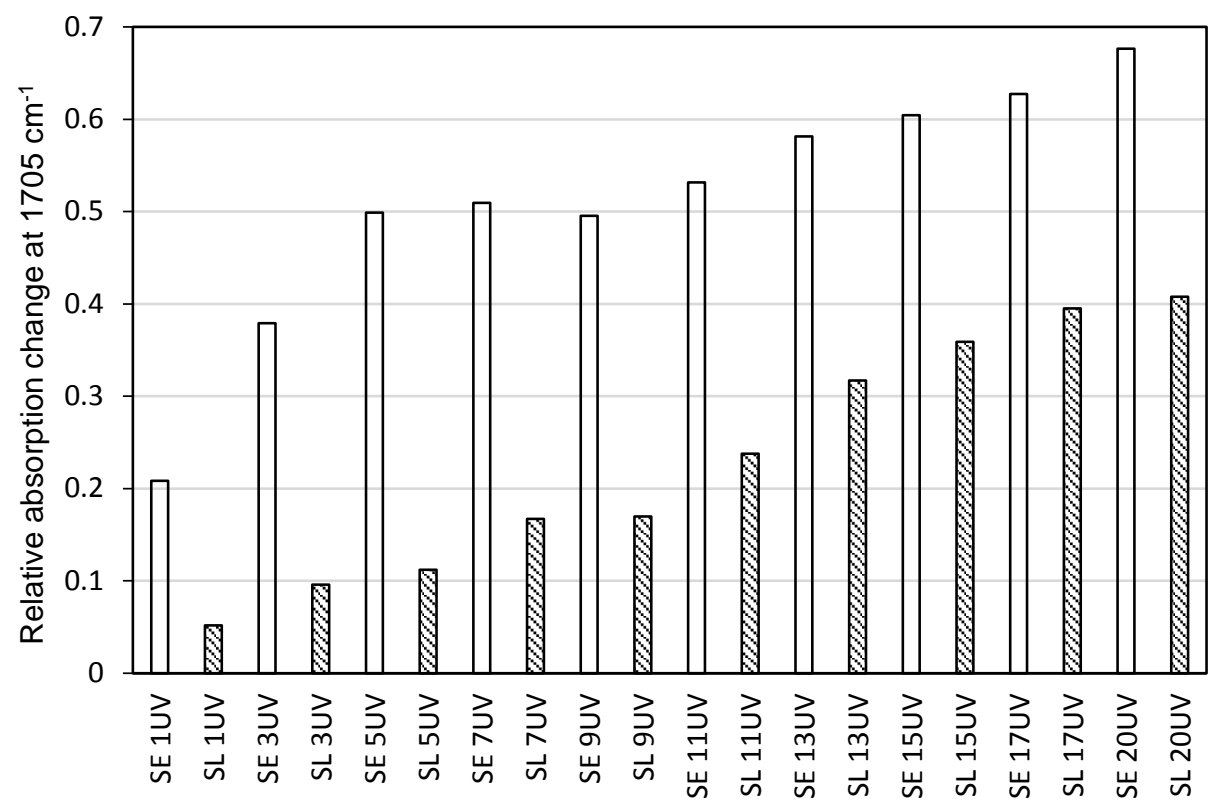

Figure 7 Absorption band intensity change of the unconjugated carbonyls at $1705 \mathrm{~cm}^{-1}$ for spruce $(S)$ earlywood $(E)$ and latewood $(L)$ generated by UV irradiation (in days)

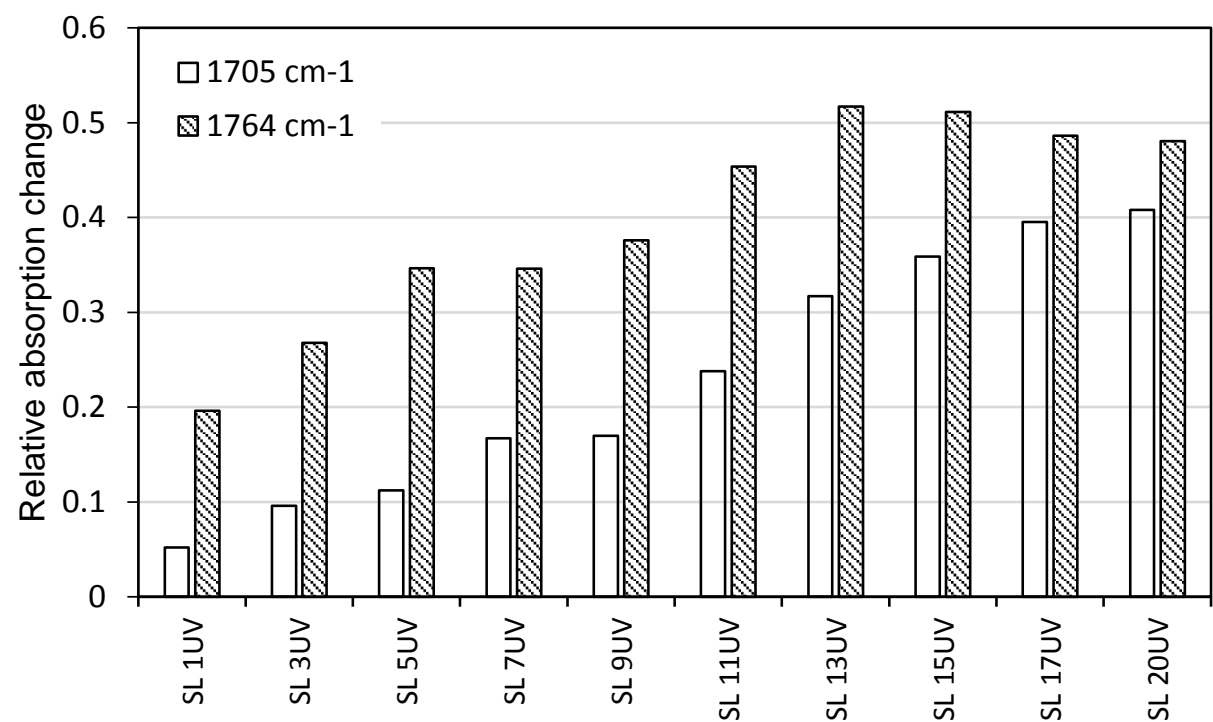

Figure 8. Absorption band intensity change of the unconjugated carbonyls at $1705 \mathrm{~cm}^{-1}$ and $1764 \mathrm{~cm}^{-1}$ wavenumbers for spruce $(S)$ latewood $(L)$ generated by UV irradiation (in days)

Figure 8 represents the differences between the absorption properties of the two types of unconjugated carbonyl groups absorbing at 1705 and $1764 \mathrm{~cm}^{-1}$. The time dependence of these two absorption increases is completely different. The band at $1764 \mathrm{~cm}^{-1}$ showed a rapid increase at the beginning of the UV irradiation. The change of the absorption increase produced a maximum on the thirteenth day of the treatment. In contrast, the band at $1705 \mathrm{~cm}^{-1}$ presented continuous increase during the whole investigated period. This difference in the growing tendency shows that the generation of these two types of unconjugated carbonyl groups (at 1705 and $1764 \mathrm{~cm}^{-1}$ ) has two different pass ways or different origins. 


\section{CONCLUSIONS}

Spruce samples with earlywood or latewood surfaces were irradiated using a strong ultraviolet light emitter mercury lamp. Chemical changes were monitored by DRIFT IR spectroscopy. The difference spectrum method was applied to determine the changes. Lignin deterioration and unconjugated carbonyl compound generation were found to be the main changes during UV irradiation. Earlywood suffered greater degradation than latewood. Most of the lignin molecules of the examined surface layer degraded during the first 11 days of UV irradiation in both earlywood and latewood. Results demonstrated that two types of unconjugated carbonyls absorbing at 1705 and $1764 \mathrm{~cm}^{-1}$ wavenumber were created during photodegradation. The time dependence of the absorption changes showed correlation between the guaiacyl lignin degradation and the generation of unconjugated carbonyl group absorbing at $1764 \mathrm{~cm}^{-1}$ wavenumber. There is no correlation between the lignin degradation and the generation of unconjugated carbonyl group absorbing at $1705 \mathrm{~cm}^{-1}$ wavenumber.

Acknowledgements: This article was made in frame of the "EFOP-3.6.1-16-2016-00018 Improving the role of research+development+innovation in the higher education through institutional developments assisting intelligent specialization in Sopron and Szombathely".

\section{REFERENCES}

Agresti, G. - Bonifazi, G. - Calienno, L. - Capobianco, G. - Lo Monaco, A. - Pelosi, C. PICCHIO, R. - SERRANTI, S. (2013): Surface investigation of photo-degraded wood by colour monitoring, infrared spectroscopy, and hyperspectral imaging. Journal of Spectroscopy 1: Paper: 380536. https://doi.org/10.1155/2013/380536

ARPACI, S.S. - TOMEK, E.D. - ERMEYDAN, M.A. - YILDIRIM, I. (2020): Natural weathering of sixteen wood species: Changes on surface properties. Polymer Degradation and Stability Paper id:109415. https://doi.org/10.1016/j.polymdegradstab.2020.109415

Bejo, L. - Tolvaj, L. - KANNAR, A. - PReKlet, E. (2019): Effect of water leaching on photodegraded spruce wood monitored by IR spectroscopy. Journal of Photochemistry and Photobiology A: Chemistry 382: Paper: 111948.

https://doi.org/10.1016/j.jphotochem.2019.111948

Bonifazi, G. - CAlienno, L. - CAPobianco, G. - Lo Monaco, A. - Pelosi, C. - Picchio, R. SERRANTI, S. (2017): A new approach for the modelling of chestnut wood photo-degradation monitored by different spectroscopic techniques. Environmental Science and Pollution Research 24: 13874-13884. https://doi.org/10.1007/s11356-016-6047-0

BRoDA, M. - POPESCU, C.M. (2019): Natural decay of archaeological oak wood versus artificial degradation processes - An FT-IR spectroscopy and X-ray diffraction study. Spectrochimica Acta A: Molecular and Biomolbiomolecular Spectroscopy 209: 280-287.

Calienno, L. - Lo Monaco, A. - Pelosi, C. - Picchio, R. (2014): Colour and chemical changes on photodegraded beech wood with or without red heartwood. Wood Science and Technology 48:1167-1180. https://doi.org/10.1007/s00226-014-0670-z

CsanÁdy, E., Magoss, E., TolvaJ, L., (2015): Quality of Machined Wood Surfaces, Springer pp 41-90.

JANKOWSKA, A. - RYBAK, K. - NOWACKA, M. - BORUSZEWSKI, P. (2020): Insight of Weathering Processes Based on Monitoring Surface Characteristic of Tropical Wood Species. Coatings 10: 877. https://doi.org/10.3390/coatings10090877

KÁNNÁR, A. - TolvaJ, L. - MAGOSS, E. (2018): Colour change of photodegraded spruce wood by water leaching. Wood Research 63: 935-946. 
LiU, X.Y. - TIMAR, M.C. - VARODI, A.M. - YI, S.L. (2016): Effects of Ageing ont he Color and Surface Chemistry of Paulownia Wood ( $P$. elongata) from Fast Growing Crops. BioResources 11(4): 9400-9420.

LIU R, ZHU H, LI K, YANG Z (2019) Comparison on the Aging of Woods Exposed to Natural Sunlight and Artificial Xenon Light. Polymer 11(4): Paper: 709. https://doi.org/10.3390/polym11040709

LIU, X.Y. - LIU, M. - LV, M.Q. - LV, J.F. (2019): Photodegradation of Three Hardwood Species by Sunlight and Xenon Light Source. BioResources 14(3): 6969-6922.

NÉMETH, K. - VANÓ, V. - FAIX, O. (1992): The effect of wood extractives on the photodegradation of wood. EWLP Conf. Grenoble, France. 191-192.

PANDEY, K.K. (2005): Study of the effect of photo-irradiation on the surface chemistry of wood. Polymer Degradation and Stability 90(1): 9-20. http://doi.org/10.1016/j.polymdegradstab.2005.02.009

PÁsZTORY, Z. - TOLVAJ, L. - VARGA, D. (2020): Effect of water leaching on photodegraded poplar wood monitored by IR spectroscopy. Wood Research 65 (6): 885-894. http://doi.org/10.37763/wr.1336-4561/65.6.885894

REINPRECHT, L.-- MAMOŇOVÁ, M.-PÁNEK, M.-- KAČÍK, F. (2018): The impact of natural and artificial weathering on the visual, colour and structural changes of seven tropical woods. European Journal of Wood and Wood Products 76: 175-190. https://doi.org/10.1007/s00107-017-1228-1

ŠTĚrbovÁ, I. - OBERHOFNEROVÁ, E. - PÁNEK, M. - DVOŘÁK, O. - PAVELEK, M. (2020): Influence of different exposition of larch wood facade models on their surface degradation processes. Central European Forestry Journal.

SANDAK, A. - BuRUd, I. - Flø, A. - ThiIs, T. - Ross GOBAKKEN, L. - SANDAK, J. (2017): Hyperspectral imaging of weathered wood samples in transmission mode. International Wood Products Journal 8: Sup. 1. https://doi.org/10.1080/20426445.2016.1237079

TeacA, C.A. - Rosu, D. - Bodirilau, R. - Rosu, L. (2013): Structural Changes in Wood under Artificial UV Light Irradiation Determined by FTIR Spectroscopy and Color Measurements - A Brief Review. BioResources 8: 1478-1507.

TIMÁR, M.C. - VARODI, A.M. - GURAU, L. (2016): Comparative study of photodegradation of six wood species after short-time UV exposure. Wood Science and Technology 50(1): 135-163. https://doi.org/10.1007/s00226-015-0771-3

TURKULIN, H. - SELL, J. (2002): Investigations into the photodegradation of wood using microtensile testing. Part 4: Tensile properties and fractography of weathered wood. Holz als Roh- und Werkstoff 60: 96-105.

TOlVAJ, L. - FAIX, O. (1995): Artifical ageing of wood monitored by drift spectroscopy and CIE $\mathrm{L}^{*} \mathrm{a} \mathrm{b}^{*}$ color measurements. I. effect of UV light. Holzforschung 49(5): 397-404. https://doi.org/10.1515/hfsg.1995.49.5.397

TolvaJ, L. - MitsuI, K. (2005): Light source dependence of the photodegradation of wood. Journal of Wood Science 51(5): 468-473. http://doi.org/10.1007/s10086-004-0693-4

TolvaJ, L. - Mitsui, K. - VARGA, D. (2011): Validity limits of Kubelka-Munk theory for DRIFT spectra of photodegraded solid wood, Wood Science and Technology 4: 135-146. https://doi.org/10.1007/s00226-010-0314-X

TOlVAJ, L. - MOLNÁR, ZS. - NÉMETH, R. (2013): Photodegradation of wood at elevated temperature: Infrared spectroscopic study. Journal of Photochemistry and Photobiology B: Biology 121:32-36. http://doi.org/10.1016/j.jphotobiol.2013.02.007

TOlVAJ, L. - MOLNÁR, ZS. - MAGOSS, E. (2014): Measurement of photodegradation-caused roughness of wood using a new optical method. Journal of Photochemistry and Photobiology B: Biology 134: 23-26. https://doi.org/10.1016/j.jphotobiol.2014.03.020

TOlvaJ, L. - TsuchiKAWA, S. - INAGAKI, T. - VARGA, D. (2015): Combined effects of UV light and elevated temperatures on wood discoloration. Wood Science and Technology 49: 1225-1237. https://doi.org/10.1007/s00226-015-0749-1 
Varga, D. - Tolvaj, L. - Tsuchikawa, S. - BejÓ, L. - Preklet E. (2017): Temperature dependence of wood photodegradation monitored by infrared spectroscopy. Journal of Photochemistry and Photobiology A: Chemistry 348: 219-225.

http://doi.org/10.1016/j.jphotochem.2017.08.040

VARGA, D. - TOlVAJ, L. - MOLNÁR, ZS. - PÁsZTORY, Z. (2020): Leaching effect of water on photodegraded hardwood species monitored by IR spectroscopy. Wood Science and Technology 54: 1407-1421. https://doi.org/10.1007/s00226-020-01204-2

YILDIZ, S. - TOMAK, E.D. - YILDIZ, U.C. - USTAOMER, D. (2013): Effect of artificial weathering on the properties of heat treated wood. Polymer Degradation and Stability 98:1419-1427. https://doi.org/10.1016/j.polymdegradstab.2013.05.004

Zivkovic, V. - ARnOld, M. - RAdMANOVIC, K. - Richter, K. - TuRKulin, H. (2014): Spectral sensitivity in the photodegradation of fir wood (Abies alba Mill.) surfaces: colour changes in natural weathering. Wood Science and Technology 48(2): 239-252.

https://doi.org/10.1007/s00226-013-0601-4 